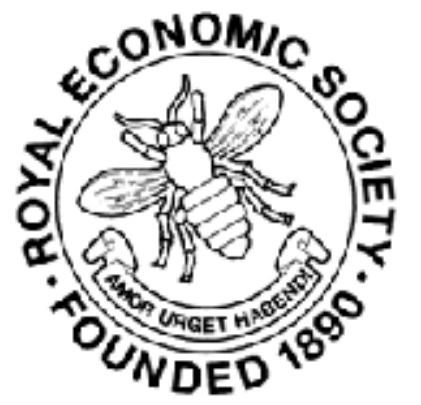

\title{
WILEY
}

An Imperial Customs Union

Author(s): J. G. Colmer

Source: The Economic Journal, Vol. 6, No. 24 (Dec., 1896), pp. 553-566

Published by: Wiley on behalf of the Royal Economic Society

Stable URL: http://www.jstor.org/stable/2957187

Accessed: 08-02-2016 12:34 UTC

Your use of the JSTOR archive indicates your acceptance of the Terms \& Conditions of Use, available at http://www.jstor.org/page/ info/about/policies/terms.jsp

JSTOR is a not-for-profit service that helps scholars, researchers, and students discover, use, and build upon a wide range of content in a trusted digital archive. We use information technology and tools to increase productivity and facilitate new forms of scholarship. For more information about JSTOR, please contact support@jstor.org. 


\section{AN IMPERIAL CUSTOMS UNION}

Colontal affairs, especially in their Imperial, as distinct from their local, aspect, have been very much to the fore during the present year. The late Earl of Derby, in 1883, when receiving, as Colonial Secretary, the representatives of the Colonies, stated that the time was not far distant when the foreign policy of England would be almost entirely concerned with the Colonies. The history of the last few years indicates that this prophecy is being fulfilled more rapidly than was anticipated. But while many of the questions that arise are of passing interest, there is one which overshadows them all-one which, to quote from a recent speech by Mr. Chamberlain, 'dominates all other Imperial interests, to which everything else is secondary, and which is at the root of the problem of Imperial Federation - the Commercial Union of the Empire. - It has been hovering on the edge of the region of practical politics since the great Colonial Conference at Ottawa in 1894, when the representatives of the self-governing Colonies passed various resolutions having for their object the extension of trade within the Empire on a preferential basis, and the removal of the obstacles which stood, and still stand, in the way of its realisation. In March last, Mr. Chamberlain, in his speech at the Canada Club, in effect invited the Colonies to make a proposition for the formation of a British Zollverein. For the first time the question was grasped boldly by a statesman of the front rank; and it is interesting to observe, as illustrating the advance of public opinion, that so unorthodox a suggestion, involving freetrade within the Empire and a revenue tariff against all other countries, met with very little opposition, even in quarters hitherto supposed to be thoroughly inoculated with free trade doctrines, and impervious to any so-called economic heresies. This bolt from the blue, as it was termed, was followed by the declaration of the award of the Judges in the Statist Competition, for the prize of 1,000 guineas offered for the best essay on an Imperial 
Customs Union. It left the matter very much where it was, the prize being divided between two papers, one dealing with it from the preferential, and the other from the free-trade, standpoint. In June, the third Congress of Chambers of Commerce of the Empire met in London, and in opening its proceedings Mr. Chamberlain made another remarkable speech, on the same lines as those which formed the basis of his remarks at the Canada Club. Commercial Union was fully discussed for two days by delegates from every part of the Empire, and, as the result, the following resolution was passed unanimously:-

That this Congress of Chambers of Commerce of the Empire is of opinion that the establishment of closer commercial relations between the United Kingdom and the Colonies and Dependencies is an object which deserves and demands prompt and careful consideration. The Congress, therefore, respectfully represents to her Majesty's Government that if the suggestion should be made on behalf of the Colonies, or some of them, it would be right and expedient to promote such consideration, and the formulation of some practicable plan, by summoning an Imperial Conference thoroughly representative of the interests involved, or by such other means as her Majesty may be advised to adopt. That copies of this resolution be forwarded to the President, the Prime Minister, the First Lord of the Treasury, the Secretary of State for the Colonies, the Leaders of the Opposition of both Houses, the High Commissioner for Canada, and the Agents-General of the other Colonies.

The resolution is by no means so colourless and insignificant as many people seem to imagine. It defines two propositions: $(a)$ that the establishment of closer commercial relations between the United Kingdom and the Colonies and Dependencies is an object which deserves and demands prompt and careful consideration, and (b) that an Imperial Conference should be called together if the Colonies, or some of them, make the suggestion, for the purpose of formulating a practicable plan. (The italics are mine.) There have been also many articles in magazines, and in the Press, dealing with what is regarded by some as the decline of Cobdenism, and by others as the development of public opinion in favour of closer commercial relations between the Mother Country and the Colonies. Not unnaturally, the proposals have met with a certain amount of criticism. This was only to be expected. The subject is an immense one, affecting every part of the Empire, and it must certainly be threshed out, from every point of view, before any real progress can be made in the solution of the problem it involves. A good deal of attention was given to it, on the occasion of the somewhat mournful celebration of the Cobden Club Jubilee, and about the same time a pamphlet 
was launched upon the world by Lord Farrer, on what he calls 'Mr. Chamberlain's neo-Protection scheme.' The close of the year seems to present a favourable opportunity for an examination of the present position of the question, in order that we may see where it now stands.

Of course Mr. Chamberlain's utterances are of the first importance, and from his position as a member of the strongest Government of modern times, overshadow other expressions of opinion on the subject, especially as his speech at the Congress of Chambers of Commerce of the Empire dealt generally with Commercial Union in all its aspects. He spoke of the three different plans which have been suggested as likely to accomplish the great object of Commercial Union-(1) The adoption by the Colonies of free trade as in England; (2) The imposition of moderate duties on certain food and raw materials imported into the United Kingdom from foreign countries, in return for a discrimination in favour of British trade in the Colonies ; and (3) The formation of a Zollverein establishing practically free trade throughout the Empire, leaving the contracting parties free to make their own arrangements with regard to duties on foreign goods, a condition of the proposal being that Great Britain should place moderate duties on the import from foreign countries of certain articles produced in the Colonies.

Mr. Chamberlain stated that to seriously consider the first proposition would be to postpone the realisation of Commercial Union to the Greek Kalends. The Colonies, speaking generally, he added, are not prepared to adopt the proposal, and besides, it would not bring about Commercial Union in the sense in which the term has been usually understood. It would be in the direction of cosmopolitan union, but would offer no particular advantage to the trade of the Empire as such. Apart from these general objections, there is the specific one that the Colonies must raise revenue. In many cases direct taxation, which would have to be adopted if the customs duties were abolished, is absolutely impracticable at present, as it would often cost more to collect than it would realise, owing to the immense areas of the outlying portions of the Empire, and the sparseness of their population. There is the further point that the Colonies in adopting free trade, and opening their markets free to the world, would have to change their present fiscal systems, and get nothing for it in return, not even preferential treatment in British markets. This proposition, therefore, is clearly out of the question at the present time, whatever may happen in the dim and distant future. 
On the other hand, Mr Chamberlain contends that the second proposal has not the slightest chance of being adopted, in a reasonable time, either by Parliament or by the country, and he describes it as ' a one-sided agreement.' The great objections to it, he states, are that it would involve a change in the whole fiscal system of the United Kingdom, and require the imposition of duties on food and raw materials. The foreign trade of this country, is so large and the foreign trade of the Colonies so comparatively small, that a preference in their markets would make so slight a difference, would be so slight a benefit to the total volume of British trade, that he does not believe the working classes of this country would consent to make a revolutionary change for what they would think to be an infinitesimal gain. Mr. Chamberlain's definition of the proposition, which in effect is that put forward by the majority of the Colonial delegates at the great Conference at Ottawa in 1894, hardly does justice to the Colonial suggestion, and this is especially the case so far as it has been understood in Canada. What the Colonies say is briefly this: "Let us have a family arrangement between the different parts of the Empire. Let us receive some moderate preferential treatment in the markets of Great Britain on the export of those articles in which we are interested, and which we now ship in more or less large quantities. In return we will extend to the products of the United Kingdom moderate preferential treatment in our markets.' This does not seem to involve a revolutionary change in the whole fiscal system of the United Kingdom, and in my judgment it cannot be regarded as a one-sided agreement. It does not seek to impose duties on all imports of food and raw materials, only on certain articles from foreign countries; similar products from the Colonies, and home products remaining duty-free as at present. The Colonies seem inclined to the opinion-and the feeling is not an unnatural one-that the domestic commercial relations of the Empire should be arranged on a slightly more favourable footing than those with other countries. They are not in a position to change immediately, and entirely, their present fiscal methods, for reasons that are obvious, and which have been admitted by Mr. Chamberlain and by Lord Farrer; but they would presumably be prepared to make concessions in favour of British products which would give them an advantage. Surely this is worth having, judging from the inroads which foreign countries are admittedly making into the Colonial trade under existing conditions. This part of the subject should be considered in relation to the recent correspondence 
between the Colonial Office and the Colonies, followed by certain exhibitions in London of foreign products and manufactures, which are competing with, and displacing, those of British make in the various Colonies.

The Mother Country is not asked to return to a policy of protection, and any duties imposed upon foreign products need only be such as to give the Colonies, whose products would remain free of duty, some moderate advantage over their foreign competitors. The articles and commodities which they export in any quantities are not more than from twenty to thirty at the outside. In the paper contributed by me to the Statist competition, the articles enumerated were about eighteen in number, and the total value of such imports in the United Kingdom in 1893 was $£ 145,000,000$, of which $£ 90,000,000$ came from foreign countries and $\$ 55,000,000$ from the Colonies. Of course, that list of articles might be increased; and in any scheme that might be adopted, changes would have to be made from time to time, both. as regards the Mother Country and the Colonies. The Colonial and Indian import trade, according to the statistics then available, was about $£ 178,000,000$, which seemed to provide a fair basis for mutual concessions. There is a tendency in some. quarters to undervalue the Colonial trade, especially in making comparisons with foreign trade. The total imports and exports of the Colonies and India amount to nearly $£ 400,000,000$, and taking the Colonies alone, it is nearly $£ 290,000,000$. About $£ 210,000,000$ of that enormous sum represents trade within the Empire. These figures are important in themselves, and afford an answer to the assertions that the fiscal policy of the Colonies has retarded the development of British trade. It must also be remembered that Colonial trade is, comparatively speaking, in its infancy. Few people will be found to deny that the Colonies present the most promising markets for the expansion of British trade in the future. Of the vacant parts of the earth's surface suitable for Europeans, the British Empire contains by far the largest area. Its occupation and colonisation must increase the markets for British products; it means the strengthening of the Empire; and it must tend to encourage the production of raw materials and food supplies, under the British flag, in larger quantities than at present. The importance of this latter consideration has been brought home to us very vividly in the last few weeks in connection with the rise in the price of bread. Although the proportions of the foreign and Colonial trade of Great Britain may not have varied much in the last twenty-five years, there is

No. 24.-VOL. VI

P P 
no doubt that the trade with the Colonies shows a greater relative increase, and it is an indisputable fact that they are much better customers per capita than any foreign countries. The average decrease in the exports to foreign countries in quinquennial periods from 1875 up to 1894, as compared with that from 1870 to 1874 , has been 15 per cent. In the exports to the Colonies and India in the same period the average increase has been 26 per cent. In the case of the Colonies, excluding India, the average increase has been 18 per cent. These figures have been criticised; but too much importance can easily be attached to the argument that from 1870 to 1874 was a period of unusual inflation, and the fall in prices since that time has affected all countries alike.

The third proposition, which Mr. Chamberlain favours, is for a Zollverein within the British Empire, leaving the component parts free to make their own arrangements with regard to duties on foreign goods, excepting that it is an essential condition that Great Britain should consent to replace moderate duties upon certain articles which are of large production in the Colonies. The objections to this proposal are much the same as those advanced in regard to the first one-that which required the adoption of free trade by the Colonies. Most of their imports come from within the Empire. Their total imports for 1893 were about $£ 139,357,000$, of which $£ 40,000,000$ only came from foreign countries. If, therefore, British imports were admitted duty free into the Colonies, either very considerable duties would have to be imposed upon foreign imports, or direct taxation established, to make up the deficiency. If, as Mr. Chamberlain admits, they will not accept the first proposition, they may find it equally difficult to favour the third, as the effects of the two schemes upon their revenues would be practically the same. If, however, a proposal to give to articles of Colonial export better treatment than is now extended to foreign exports would not be unfavourably received in the United Kingdom, in return for the establishment of a Zollverein, surely some compromise which would insure moderate preferential treatment to British trade in every part of the Empire is not impossible? The adoption of such a scheme would not entail any great sacrifices either on the part of the Mother Country or the Colonies, but it would be a commencement of a better order of things, and, as $\mathrm{Mr}$. Chamberlain has said, ' gradually, therefore, by that prudent and experimental process by which all our greatest institutions have been slowly built up, we should in this way, $\mathrm{I}$ believe, approach to 
a result which would be little, if at all, distinguished from a real federation of the Empire.' The possibility of a compromise appeared to be contemplated, as he stated that 'of course the details of such a scheme would require the most careful examination. There may have to be exceptions made to the principle, although I believe the principle itself must be adopted if any progress is to be made at all.' No one nowadays, in this country or outside of it, denies, as Mr. Chamberlain says, the enormous benefit that it would be to the British race throughout the Empire if we could arrange some union which would lead to closer commercial relations and retain within the Empire the trade and the people now diverted to foreign countries.

The desire for a commercial arrangement between the Colonies and the Mother Country is the outcome of a sentiment in favour of drawing closer the bonds of union while the time is opportune. Lord Jersey, in his report on the Ottawa Conference, wrote :-

The Mother Country is asked to help in keeping clear the channels between her Colonies and herself, so that the flow of trade may be increased and the feeling of kinship uninterrupted. Never, perhaps, in our Empire's history has such an opportunity presented itself. The 'passionate sentiment' of Canada, as Sir John Thompson so well described it, and the hopeful attachment of the 'growing Colonies of Australasia and the Cape,' turn eagerly at this time to the Mother Country for some sign of her regard for their development. Their leading statesmen appreciate the value of the connection with Great Britain, and the bulk of their population is loyal. It is within the power of Great Britain to settle the direction of their trade and the current of their sentiments for, it may be, generations. Such an opportunity may not soon recur, as the sands of time run down quickly. There is an impatience for action which would be tried by delay, and most sadly disappointed by indifference to the proposals which are now brought forward.

Some critics seem to think that we ought to be thankful for what the past has done for us, and leave the future to take care of itself. Lord Farrer does not think much of the resolution of the Congress of Chambers of Commerce of the Empire, but it is only fair to state that, apparently, he does not appear to have grasped its meaning. In speaking of Canadian affairs he declares that Sir Charles Tupper's baneful guidance has been withdrawn, and that the country has declared for a ministry which is opposed to the principle of protection. But he does not seem to be aware that Mr. Laurier is as much in favour of preferential trade as was Sir Charles Tupper. There may be some difference as to details, but in principle they are agreed, judging by the public utterances of the present Premier on the subject. Speaking at Toronto in June last, he stated that 'he 
agreed with Sir Charles in some respects, notably in the new idea of preferential trade which he was advocating. It was. fraught with possibilities of greatness for the Canadian people and for the British Empire at large. After fifty years of self-government in the Colonies, the new principle was proclaimed that there should be preferential trade between the Empire at large. That was to say that Great Britain and her Colonies should trade by having a preference not enjoyed by other nations. That was. a great principle.' Many of the other arguments in Lord Farrer's. pamphlet seem to be based on false premisses. If this can beproved, the conclusions certainly cannot be regarded as sound, and the propositions with which he deals may not be so ' undesirable and impracticable' as they are described. Preferential treatment in the United Kingdom of Colonial products cannot with accuracy be called protection, and in the Colonies the tendency of such an arrangement would be in the direction of freer trade with the United Kingdom than at present.

A good many of Lord Farrer's arguments are based on the assumption-a very erroneous one - that the effect of any new arrangement of the kind would be to close the markets of Great Britain and the Colonies to foreign goods. 'Mr. Chamberlain's proposal,' he says, 'is to close markets and not to open them, to make them (the British people) adopt a system which will shut out foreign goods, anddeprive them pro tanto of foreign markets for their own products.' And again, 'that the proposal if accepted would open their (the Colonial) markets to one another and to the rest of the Empire, but would close them or keep them closed to the rest of the world.' Another erroneous assertion is that in Mr. Chamberlain's scheme the proposed duties are to be of such an amount and character as to secure to the Colonies the exclusive possession of the markets of the United Kingdom. The plan is also referred to as equivalent to a treaty 'which would bind England to exclude the low-priced corn, meat, wool, and sugar of the United States, of Russia, of Argentina, of France, and of Germany, in order that she may obtain these articles at a higher price from Canada, India, Australia, and the West Indies.' And again, 'What shall we say to a treaty that binds Canada and Australia to buy no articles from the United States or from China which those Colonies can buy, although at a higher price, from Great Britain, or from India?' Lord Farrer evidently imagines that another object of the scheme is to deprive the United Kingdom of necessaries from the United States, alone 
valued at $\$ 46,000,000$, besides an immense quantity from other countries, on the empty promise that Canada's $\$ 11,500,000$ will, under the encouragement given by a different duty, grow into the larger amount. 'We are, therefore, asked,' he adds, 'looking to the United States alone, to sacrifice a trade which has in forty-one years grown from $£ 51,000,000$ to much more than $£ 115,0.00,000$, for the smaller trade of the Colonies.' Statements to a somewhat similar effect could be quoted from Lord Farrer's pamphlet ad nauseam, but just one other: 'In other words to exclude those articles when coming from foreign countries, including the United States, in order to encourage imports from the Colonies, including Canada.' These quotations are in themselves sufficient to show the nature of the arguments Lord Farrer employs. It would be difficult for any one to find in Mr. Chamberlain's speeches, or in the other reasonable proposals that have been put forward for the solution of the problem of Commercial Union, anything which could support such statements. A moderate duty (those are Mr. Chamberlain's words) in England on certain articles in which the Colonies are interested would not exclude such imports from foreign countries. Lord Farrer would be the first to deny that the import duties imposed by foreign countries have excluded British goods. If any scheme of the nature suggested were to come into operation, the foreign exporters would have to pay the slight duties, in order to compete with similar home products, and with imports from the Colonies which would remain free of duty. The result would be that the revenue would be somewhat increased, without adding materially to the prices of commodities. The Colonial exporters would get a greater return for shipments of a like kind than foreign exporters would do-the difference being represented by the moderate duty. This would be an advantage to the Colonies, and would undoubtedly tend to stimulate their development and their exports to the Mother Country; and according to Lord Farrer the more the Colonies sell to the Mother Country, the more must they buy of British products!

Another assertion is that commercial federation must lead to a serious limitation of the markets for British manufactures, for, if we do not buy from foreign countries, we shall not sell to them; Lord Farrer does not endeavour to prove this hypothesis. The duties imposed upon imports by other nations have certainly not led to a restriction of their exports. An examination of trade statistics, and an inquiry of our large exporters, will prove that British trade is subject to increasing competition from 
other nations, notwithstanding the wickedness of their fiscal' policies, and that it has been growing more intense during the period of peace that has prevailed during the last twenty-five years. If the exports of foreign countries have not fallen off, why should a much more moderate system of duties in the United Kingdom operate in a different manner? Another bogey advanced by Lord Farrer is that of the possibility of retaliation. He states, 'if and so far as we cease to import from the United States, we shall cease to export to them, and we shall thus cripple our exchange with that great country. Nor is this all. The Government of the United States have both the power and will to retaliate by imposing differential duties on our trade.' Our exports to the United States have not increased materially in the last twenty-five years; but our imports from them have doubled; and we have to pay for them in some way or another, whether it is by our 'invisible exports' or not. We take from the United States, and the same thing applies to many other countries, very much more than we send to them. It is idle to assert that commercial union would exclude the products of the United States. They must sell their products and the United Kingdom is the principal, and nearly the only, market they have for many of them. They have no right to complain or to protest against freer relations between different parts of the British Empire. They have free trade within their own Republic, and very high duties on foreign imports. In effect, by adopting commercial union we should only be imitating in principle the example they and other nations have set for usthat of treating our kith and kin as such, without, however, making the very marked discrimination against others that many of our competitors appear to favour.

All through the pamphlet the Colonial trade is belittled, and the Colonies are sneered at. The glories of the past seem to be of more importance than the present condition of affairs, or the probable expansion of British trade in the future. Sufficient for the day is the evil thereof, and let posterity take care of itself. No credit is given to the Colonies for having made their tariffs lower as a rule than those of foreign countries. It is the fashion to scold them for having, when allowed to run alone, failed to adopt the methods of the Cobden Club. 'Would it not be the policy of a fool,' says Lord Farrer, 'to sacrifice an existing threequarters to the chance of increasing one-quarter, to restrict the business of nearly $£ 500,000,000$ for the problematical chance of increasing a business of nearly $£ 150,000,000$ ?' There is no 
question of sacrificing the foreign trade ; and the figures do not give a fair idea of what the Colonial trade is in comparison with the foreign trade. The total imports (including the transit trade) of the United Kingdom from foreign countries in 1895 were $£ 321,159,000$ and from British Possessions $£ 95,530,000$. The exports of British and Irish produce to foreign countries in the same year were $£ 155,888,000$, and to British possessions $£ 70,001,000$. There is little doubt that in the future the Colonial trade will be much greater than it is now, and may even surpass that of the United Kingdom. Would it not be wise to take measures at the present time, and in the present condition of affairs, which would ensure to the Mother Country the largest share in the expansion which appears to be inevitable?

Another good old theory is brought into prominence. We are told that British trade statistics teach that nations cannot sell without buying, and that they should ' take care of the imports, and the exports will take care of themselves.' This maxim of the free traders does not seem to have been attended with very favourable results to British trade in the last five and twenty years-at any rate so far as the exports are concerned. Other nations seem to follow the opposite theory of looking after the exports, and letting the imports take care of themselves. As an hypothesis, Lord Farrer puts forward the possibility of a tariff revulsion in the United States, and asks us to suppose that if it were to come the first form it would take might be that of reciprocity. Then assuming that the United States Government were to come to us and say, 'We will open our markets to you, but it is only on condition that your markets are open to us,' and assuming, he says, that our Government were obliged to answer, 'No, thank you ; much as we should like your market we cannot accept it, for we have made engagements with Canada by which we are bound to keep your goods out of the market.' ' Is it possible,' he adds, 'to conceive anything more likely to make Englishmen say-what I devoutly trust they may never say-Perish Canada?' This is a fair sample of Lord Farrer's arguments. As already mentioned, there is not the slightest idea of any arrangement between the Mother Country and Canada, or any other Colony, by which United States goods would be excluded. It is absurd on the face of it; but it is not cheering to the Colonies to know that if it became a question of the Colonies or foreign countries in matters of trade, a certain section of their fellow-subjects might be prepared to give them the go-by. That was thought to be a thing of the past! 
It is refreshing to turn from Cobden Club criticisms to the speech of Mr. Chamberlain, who is a practical man of commerce, and no mere theorist. He stated :-

I think that further knowledge must tend to complete the agreement between us, and that it will bring within the range of practical politics that splendid dream which has been cherished by all the greatest and most patriotic statesmen both at home and in the Colonies, when we may reach a union in which free States, all of them enjoying their independent institutions, will yet be inseparably united in defence of common interests and the pursuit of mutual obligations, and will be held together by ties of affection, of blood, and of religion.

As we come to the conclusion of Lord Farrer's pamphlet there are hopeful signs that, after all, we may perhaps be able to enlist his sympathies on the side of preferential trade. That his thunderbolts against the scheme are based on false premisses must be sufficiently clear to the impartial mind. But his heart is all right. He admits that it would be a most desirable consummation to have no duties on British goods throughout the Empire, or no duties which operate so as to protect one part of the Empire against the rest. 'But alas!' he adds, 'this goes further than the most ardent free traders expect, further than will probably for generations to come be practicable.' This certainly clears the way somewhat. If we cannot have free trade, let us try for the next best thing, freer trade within the Empire. Lord Farrer.states that all the Cobden Club hope for is to see some approximation to such a consummation. That is what "preferential traders' are aiming at. He recognises the difficulties of the Colonial position when he states that the Colonies must, for some time, at any rate, raise revenue by duties which can hardly fail to be, to some extent, protective. I do not like the term protective, but it is a favourite word with Lord Farrer, and is important in connection with the sentences that follow. As a reasonable free trader, he would also regard it as unwise and unjust that a system of protection which has been in force for many years, and under which new industries of various kinds have grown up, should be abolished at a single blow. What he desires to see is the abandonment of protection, as a theory, by the Colonies, and the gradual reduction of the most obnoxious of their present duties, but he feels that it is out of the question to do this except cautiously and by degrees, as indeed was done in the United Kingdom. What more could be said in favour of the Colonial contention by the most ardent believer in Commercial Union? Canada has been doing what he recommends for some time past. 
The amount per head of customs duty, which in 1890 was $\$ 5$, has been gradually falling off until in 1895 it was only $\$ 3.47$ per head, and it is more than likely that, under the present administration, this policy will continue and perhaps develop with even greater rapidity than it has done in the past. He lays down as a maxim that free traders are not necessarily fanatics; and also that freedom of thought, freedom of social and political intercourse, are even more essential to general welfare than freedom of trade, and that if these conflict with freedom of trade, then freedom of trade must give way. Surely the bringing of the Mother Country and the Colonies into closer Commercial Union is desirable and essential to the general welfare. This must have been passing through his own mind, for he says that trade concerns material interest, while real friendship and harmony of feeling between the English speaking races are objects for which it may be worth while to make some sacrifices of such interests, and that if the doctrines of free trade are really in conflict with such interests and aspirations, they may have to give way. At the same time, however, he challenges the 'advocates of protection' to show 'that the steps they urge would promote the harmony we both desire.' Preferential traders are not advocates of protection. Their object is to arrange for freer trade within the Empire, and the lowering of Colonial tariffs in favour of British goods in return for moderate concessions in the United Kingdom; and they do not propose to exclude foreign goods from the British markets.

There cannot be much doubt, therefore, that a compromise is practicable, between the different plans proposed, out of which Commercial Union may develop-probably on the lines of the second and third propositions already mentioned, and it would not be surprising if, in the long run, Lord Farrer were found to be acting as fairy god-mother to a bold commercial policy of Preferential Trade within the Empire. In details there may be differences, but in principle all parties seem to be agreed. Mr. Chamberlain is of the opinion that the suggestion must originate with the Colonies. That may possibly be the outcome of the resolution of the Congress of Chambers of Commerce of the Empire. It is a question, however, whether some stimulus is not needed on the part of the Mother Country, the head of the Empire, to which the Colonies all look for guidance and counsel. The problem is certainly an Imperial question in the widest sense of the term. If her Majesty's Government could see its way to communicate with the Colonies, asking for an expression of opinion 
on Commercial Union valuable information would be elicited, and the way paved for an Imperial Conference to consider the formulation of some practicable plan. Such a gathering would be a fitting opportunity of celebrating the sixtieth year of the glorious reign of her Most Gracious Majesty-of the achievements of which her subjects in the outlying portions of the Empire are as proud as those who live within the limits of the United Kingdom. Of course, nothing can be done until the German and Belgian treaties have been modified. They absolutely bar the way to. Commercial Union, and it would give much confidence to the Colonies, and show that the Mother Country is in earnest, if some steps could be taken to procure the abrogation of the obnoxious clauses in what Lord Salisbury has termed 'those unlucky treaties.' Limits of space forbid my dealing at greater length with this part of the subject, and with many other points in connection with the matter. But, as stated in my article in the National Review in July last, there is no doubt that closer commercial relations are feasible if they are approached in a broad spirit of compromise. Certain principles must be kept in view in the negotiations, if they are to bear fruit in the near future. The scheme must be simple and moderate in its incidence in the United Kingdom, and must interfere as little as possible with free trade. The same remark applies to the fiscal conditions obtaining in the Colonies; and certainly no scheme will have any chance of acceptance which involves the giving up of any of their powers of self-government. Any closer union must inevitably be on a commercial basis, and out of such an arrangement will surely grow an Imperial Council, giving the Colonies a voice in Imperial affairs, and, in all probability, a fund for the better defence of the outlying portions of the Empire, although it may not take the form of a direct contribution to the navy. No more important subject is before the statesmen of the Empire at the present time, and to quote once more from Mr. Chamberlain's speech, 'its discussion must have some direct result in bringing us nearer to the object which we all have in view, and which I do not hesitate to say is the greatest object which Britons can pursue in what I believe to be a critical stage of Imperial history.'

J. G. Colmer 